\title{
Creating networks, creating in-groups: Choice of vocabulary in The Economist editorials
}

John Mullen

\section{(2) OpenEdition}

Electronic version

URL: http://journals.openedition.org/asp/2454

DOI: $10.4000 /$ asp. 2454

ISBN: 978-2-8218-0380-0

ISSN: $2108-6354$

Publisher

Groupe d'étude et de recherche en anglais de spécialité

Printed version

Date of publication: 1 December 1999

Number of pages: 253-266

ISSN: 1246-8185

\section{Electronic reference}

John Mullen, « Creating networks, creating in-groups: Choice of vocabulary in The Economist editorials », ASp [Online], 23-26 | 1999, Online since 01 September 2011, connection on 19 April 2019. URL http://journals.openedition.org/asp/2454; DOI : 10.4000/asp.2454

This text was automatically generated on 19 April 2019

Tous droits réservés 


\title{
Creating networks, creating in-groups: Choice of vocabulary in The Economist editorials
}

\author{
John Mullen
}

1 The dominance of English in world business is massive and the growing internationalisation of production ensures, for better or for worse, that this trend will continue. Already in 1986, McCrum could write that three quarters of the world's mail was written in English and "nearly half of all business deals in Europe were conducted in English". Claude Truchot (1994) described the situation within the scientific research communities (95\% of researchers in Strasbourg claimed to give papers in English) and within some international companies.

2 What can be said about the nature of international English? In specific areas or technical specialities, careful work has allowed the beginnings of a description of the language used. Academic English and the English of research papers have been particularly examined (among many others, Swales 1990, Sturge Moore 1997, Lerat 1997). But what of English in a business context?

3 English is used in business for communicating product orders, technical specifications, timetables, financial reports, complaints or technical back-up in the whole world, between non-native speakers most frequently, or between native and non-native speakers. It is also used for other purposes of communication both within and between companies: persuading, proposing, analysing, negotiating, and discussion of strategy. Already, certain international companies, such as the Swedish company, Ericsson, (Hollqvist 1984) impose English as the language of business meetings, even when all staff present have the same mother tongue (in this case, Swedish).

4 In Italy, the company Bari has attempted to make English the only language used even for internal memos, and other examples have been known. ${ }^{1}$ 
5 For the carrying out of routine business tasks (ordering spare parts, sending out bills, setting up appointments, and various standard forms of business letter) a restricted vocabulary and a text heavily marked by set forms is sufficient. This is illustrated by the frequent use within firms of such aids to communication as technical phrase books, collections of form letters in English, automatic translation programmes, and so on. Such phenomena have led many people to speculate that international business English in general is becoming or will become "simplified".

6 Another hypothesis one frequently hears concerning English in international business is that the language will become completely detached from its cultural roots. The British Council sponsored major work, The Future of English, speculates that soon English will no longer be dependent on those countries which have it as a mother tongue.

The main areas of development in the use and form of English will undoubtedly come from non-native speakers. Native speakers may feel the language 'belongs' to them, but it will be those who speak English as a second or foreign language who will determine its world future. (From The Future of English)

7 Dr. Merton Bland, intervening in an e-mail discussion on the cultural roots of English, suggested that

Yes, we can still talk about the "sticky wicket" or "fourth and goal," so culturally-

bound. But, increasingly, we use a technical vocabulary that, itself, is international.

In this way, it has been suggested, global English will have succeeded where Zamenhof's Esperanto failed, in becoming a language independent of particular cultures. One often hears, and perhaps particularly among professionals of English language teaching, negative opinions about such developments. The following quotation from a contribution to an English language teachers' e-mail discussion list is quite typical:

Well, I'm not sure I'd want to see a world English. Or rather, I have mixed feelings about it. Teaching World English (after we've somehow defined it) means teaching an English that has no native speakers, an artificial dialect if you will. [...] and it wouldn't change over time very easily. (And then, the changes would be abrupt, not natural, etc.) (10.11.98 on TESL-L, a discussion list for English as a foreign language teachers.)

9 What this paper aims to do is to look at the lexis of one example of English as an international language of business - the editorials of The Economist, and consider whether there is evidence that it is tending towards simplification or internationalisation in the sense of a separating of the language from its cultural roots. Potential explanations for the choice by The Economist of this type of lexis will then be explored, using some concepts taken from discourse analysis.

10 The Economist, published by the British press group Pearson who also publish the Financial Times is a highly respected magazine dealing with economic, business and other issues. According to its promotional material, it is read by "over 450000 of the world's most prominent business figures" (sales leaflet May 1998) which, even allowing for a certain poetic licence, shows the audience it is aiming at -fundamentally, managers and shareholders.

11 There are several things that distinguish it from similar magazines around the world. Perhaps the first is its determinedly modern style. Humorous cartoons, rather than portraits of smiling shareholders, can often be found on the front page. The second is its capacity to be controversial. The editorial line is, for example, at the same time 
conservative and republican - that is, in favour of the abolition of the British monarchy, a rather unusual and heady mixture in British journalism. Jacques Hennot (1993) writes

The Economist [...] imprimé en noir et blanc, doté d'une maquette sévère [...] est pourtant considéré comme un des plus influents dans les milieux internationaux. [...]Très jaloux de son indépendance, il n'hésite pas à prendre des positions iconoclastes. Il fit sensation, voici quelques années, en défendant le libre commerce des drogues douces.

12 Finally, The Economist is particular in that it doesn't allow its writers to sign any of its articles -the authors remain anonymous. It aims at convincing its readers of its analyses by careful documentation and evidence, and not by an appeal to the authority of wellknown "experts".

The Economist is very much an international magazine. "The Economist may be published in English, but it covers the world", states its promotional material. The magazine is sold in local newsagents around the world. Poster advertising campaigns in France and Germany recently encouraged the general public to buy it. Its cover price is stated in thirty-five currencies. Subscriptions (very unusually for a British magazine) can be paid for in cheques in any major currency.

14 The Sales Manager of The Economist was willing to give the latest audited sales figures (see Table 1).

Table1. Weekly circulation figures for January-June 1998

\begin{tabular}{|l|l|}
\hline UK & 119,400 \\
\hline Europe & 147,539 \\
\hline Asia Pacific & 79,500 \\
\hline Middle East/Africa & 18,739 \\
\hline Latin America & 17,432 \\
\hline North America & 301,806 \\
\hline World & 684,416 \\
\hline
\end{tabular}

COMMUNICATED BY E MAIL

15 The Economist is sold both to native speakers of English and to non-native speakers, but substantially different editions are not used for non-Anglophone countries.

We produce 5 editions round the world. The advertising is different in each edition, but the editorial is the same throughout, apart from the Britain section, which usually has 3 extra pages in the UK edition. Depending on the news, we do quite often have split covers which might mean, for example, that UK and Europe editions have one cover and the Far East and US another. However, this does not mean that the leaders are different, just that they would swap positions as the first leader always relates to the cover. (Interview with author)

Within the magazine, we chose to look at the editorials, the "leaders". There are several of these in each issue. Other established newspapers such as The Times also have several per issue, but The Economist spends more pages on editorials than any other magazine or 
newspaper we have seen. The editorials give a clear opinion on a subject of international or national business, diplomacy, economics or politics. They are the part of the magazine in which the writers address themselves most immediately to the readership to try to convince them of a viewpoint. From this point of view the language and vocabulary used would, we felt, reflect some aspects of the relationship between (anonymous) writer and reader.

We asked one of the editorialists of The Economist if they had any particular policy relating to the type of language preferred in their magazine. He assured us that they did not, but that their only aim was to be "as clear as possible" and to "avoid jargon".

Comments related to this attitude appear frequently in the magazine: "we are committed to plain English". The word "committed" is normally reserved for ideological or ethical considerations, and its use to describe a style of language shows an emotional attachment.

The Economist tries to maintain a clear concise prose style [...] On the readability scale devised by Donald Hayes of Cornell University (which has a baseline of zero for "International English-language newspapers", and rises to +50 for the most difficult papers in research journals such as Nature)...The Economist scores minus two. (The Economist 7.11.98)

Interestingly, Jacques Hennot in his study of the economic and financial press (1993), also singles out the English used in The Economist for comment. He refers to it as "écrit dans un anglais très pur". "Plain English" and "un anglais très pur" are both intended to be high praise, but filtered through different cultural and intellectual sets of values.

For the purposes of this study, twenty editorials were selected at random, each approximately one page long, from twenty different issues of The Economist covering the period from 1994 to 1998. The themes covered are very varied, but deal in the main with international economy, business and politics. We aimed to examine the difficulty of the vocabulary for the non-native speaker, and whether or not the vocabulary was partially culture-bound or entirely international and "culture-free".

The lexical difficulty of a text is not something which can be easily measured, in particular for an international audience, since the similarity or dissimilarity of a lexeme to the words of their native language is a major factor (speakers of romance languages find latinate vocabulary easier than Anglo-Saxon based vocabulary, for example).

The vocabulary was examined in two ways -first the impressions of a group of contacts were collected, in order to identify the lexical elements which cause difficulty, and secondly the frequency of these lexemes in a large general English corpus was investigated.

With the help of non-native speakers (who were not teachers of English, since teachers are a specific category not intended to be the target of the magazine), we read through the editorials and picked out as much as possible of such vocabulary. We divided it by grammatical category and added three categories more culture-based than grammatically based: foreign words, cultural references, proverbs and idioms.

Next a straw poll was carried out among foreign speakers of English. We asked a group of foreign contacts (again not English teachers), to list the words they were sure they understood, those that caused great difficulty but were not impossible, and those they were sure they didn't understand. We asked two Danish contacts who are in the habit of participating in international conferences, a French contact married to an Englishman, 
who has lived for a year in Australia, two German contacts who have a good conversational level of English, and an Algerian who learned English at home. From our experience with managers in international firms, we consider that our contact group has a level of English much higher than the average target audience among non-native speakers, of The Economist. Nevertheless, a large number of lexical items posed problems for them. Between 19 and 89 lexemes were considered as "completely incomprehensible" and a similar number "caused severe difficulty".

Naturally, such results are impressionistic and are not amenable to statistical analysis. Nevertheless, this straw poll allowed a selection of lexical items for further examination.

We decided to examine them from the point of view of frequency in modern English usage. It seemed to us that if "plain English" had a meaning at a lexical level it ought to be close to "everyday English". To carry out this investigation, we used the British national corpus, the largest corpus we could find.

The British National Corpus is a collection of texts of modern English, making up one hundred million words of text. This makes it considerably larger than most (the Cobuild corpus of British English contains less than 18 million words). It deals with British English, which seemed to us appropriate since The Economist is a British magazine. By a process of sampling, the BNC team ensures that the corpus is genuinely representative of modern English. The corpus includes many different styles and varieties, and is not limited to any particular subject field, genre or register. In particular, it contains examples of both spoken and written language. For written sources, samples of 45,000 words are taken from various parts of single-author texts. Shorter texts up to a maximum of 45,000 words, or multi-author texts such as magazines and newspapers, are included in full. Sampling allows for a wider coverage of texts within the 100 million word limit, and avoids over-representing idiosyncratic texts.

Looking first at nouns, we found that our sample of twenty editorials included the following words which some at least of our respondents claimed to find very difficult. For some of the words we have added the immediate context. After each word is a reference number which refers to one of the twenty editorials used, and a number which represents the frequency of apparition of this lexeme in the British National Corpus.

In measuring frequency within the British National Corpus, we attempted to include occurrences of any word which would sufficiently clarify the meaning of the lexeme. So naturally we included plurals, related adjectives or verbs if the meaning was essentially the same, etc. For example, we counted both the verb to flip-flop and the noun a flip-flop, and for the item bullying we included bully, bullies, bullied, (but not to bully off, the technical hockey term). On the other hand, we eliminated from the frequency figures for brace meaning pair such occurrences as a brace for his neck.

We came up with this list for nouns in the editorials. We have listed the words in order of "rarity", that is, at the beginning are the nouns used in the editorials that are least frequently found in the BNC.

\section{Table 2. Nouns}

\begin{tabular}{|l|l|}
\hline grouplet (D15) & 1 \\
\hline a patsy (D13) & 5 \\
\hline
\end{tabular}




\begin{tabular}{|c|c|}
\hline soft-headedness (D8) & 7 \\
\hline Give-and-take (D5) & 11 \\
\hline jet-setting (D4) & 11 \\
\hline back-pedalling (D5) & 11 \\
\hline wooziness (D13) & 14 \\
\hline war-weariness (D15) & 15 \\
\hline basket-case (D3) & 18 \\
\hline shilly-shallying (D5) & 19 \\
\hline dotage(D20) & 20 \\
\hline geek-hero (D20) & 20 \\
\hline whoops of delight (D17) & 22 \\
\hline backsliding (D5) & 29 \\
\hline more politicking than policy making(D1) & 29 \\
\hline tittle tattle (D9) & 30 \\
\hline scrutineer (D9) & 33 \\
\hline hoodlum (D15) & 36 \\
\hline a dreary has-been (D13) & 44 \\
\hline a stop-gap (D13) & 45 \\
\hline stooge (D1) & 56 \\
\hline a bromide (D16) & 59 \\
\hline a flip-flop (D5) & 71 \\
\hline a brace of regional governors (D13) & 74 \\
\hline stakeholder (D6) & 77 \\
\hline Nice pickings(D20) & 112 \\
\hline an inkling (D12) & 159 \\
\hline externalities (D6) & 202 \\
\hline a pundit (D8) & 207 \\
\hline
\end{tabular}




\begin{tabular}{|l|c|}
\hline a showdown (D11) & 232 \\
\hline a backlash (D20) & 269 \\
\hline a blight (D7) & 308 \\
\hline a spur (D14) & 482 \\
\hline big-power bullying (D17) & 716 \\
\hline
\end{tabular}

The main categories of difficulty seemed to be:

- complex nouns (soft-headedness, jet-setting, back-pedalling, give-and-take war-weariness, shillyshallying, has-been, tittle tattle, stop-gap, flip-flop). This category causes problems because of the large variety of semantic links possible between the two or more elements of the complex noun (weariness [of] war, but [be] ing [part of the] jet set, and a hero [for] geeks).

- informal or occasionally slang words (wooziness, shilly-shallying, geek, whoop, flip-flop).

- Elements of irony (brace, grouplet, basket-case). Irony is particularly interesting in this context in that avoiding ironic expressions is a basic tactic for increasing comprehensibility when addressing non-native speakers.

31 Among the difficult adjectives identified by our contact group were the following (see Table 3).

Table 3. Adjectives

\begin{tabular}{|l|l|}
\hline hair-trigger (D17) & 4 \\
\hline clunky circuits (D14) & 6 \\
\hline gridlocked & 20 \\
\hline skin-deep (D14) & 12 \\
\hline uncool (D19) & 15 \\
\hline cornered (D5) & 29 \\
\hline a groggy boxer & 33 \\
\hline gung-ho investors (D14) & 33 \\
\hline rough-hewn (D13) & 38 \\
\hline stodgy (D13) & 51 \\
\hline swingeing penalties (D17) & 52 \\
\hline trumpeted expectations (D17) & 53 \\
\hline a go-it-alone country (D11) & 91 \\
\hline
\end{tabular}




\begin{tabular}{|l|l|}
\hline outlandish (D9) & 103 \\
\hline crass(D16) & 103 \\
\hline arcane (D6) & 119 \\
\hline limp (D1) & 120 \\
\hline grudging(D1) & 147 \\
\hline stunted.(D18) & 147 \\
\hline beastly (D19) & 148 \\
\hline flailing (D5) & 158 \\
\hline bloated (D17) & 169 \\
\hline awash (D19) & 173 \\
\hline muddled (D4) & 249 \\
\hline aloof (D16) & 290 \\
\hline gruesome (D19) & 209 \\
\hline half-hearted (D19) & 330 \\
\hline skinny copper wire (D14) & 319 \\
\hline far-reaching (D15) & 135 \\
\hline dizzying(D1) & 231 \\
\hline over-mighty (D9) & 1030 \\
\hline elder (D18) & 130 \\
\hline
\end{tabular}

Looking at these adjectives, we found some identifiable sources of difficulty:

- a number of complex adjectives (Carriage-borne, hair-trigger, gung-ho, go-it-alone, skindeep, over-mighty, half-hearted, rough-hewn, far-reaching, skin-deep). Again, the variety of semantic structures causes difficulty (deep [as the] skin but [with a] trigger [like a ] hair, [with] half [of a] heart, hewn [in a] rough[manner] and so on).

- a group of adjectivally used present participles: Swingeing, dizzying, flailing, grudging

- several formal or literary adjectives: Aloof, arcane, awash, elder

- some slang or informally used adjectives: Groggy, stodgy, limp, skinny, clunky

- the ironically used, out-of-date informal adjective, beastly

Looking now at verbs, we found the following results (see Table 4). 
Table 4. Verbs

\begin{tabular}{|c|c|}
\hline to floor(D7) & 3 \\
\hline to tinge (D13) & 4 \\
\hline to bedevil (D5) & 11 \\
\hline to mob (a building) & 17 \\
\hline to sack (a city) & 31 \\
\hline to recoil (D18) & 36 \\
\hline to laud (D8) & 38 \\
\hline to trounce (D6) & 46 \\
\hline to nibble(D1) & 53 \\
\hline to tut-tut (D1) & 56 \\
\hline to ditch (D6) & 82 \\
\hline to tinker (D17) & 91 \\
\hline to bestow (D8) & 103 \\
\hline to lumber (D14) & 112 \\
\hline to assuage & 114 \\
\hline to dash (D16) & 191 \\
\hline it was marred (D19) & 121 \\
\hline to bolster (D17) & 223 \\
\hline to swamp & 261 \\
\hline to tick. (D18) & 262 \\
\hline to haul home & 567 \\
\hline to sneer (D6) & 530 \\
\hline to enshrine (D15) & 376 \\
\hline to nudge the balance (D4) & 404 \\
\hline to unravel (D15) & 406 \\
\hline to dwindle (D15) & 495 \\
\hline
\end{tabular}




\begin{tabular}{|l|l|}
\hline to underpin (D10) & 690 \\
\hline to scrape & 732 \\
\hline
\end{tabular}

We looked separately at phrasal and prepositional verbs, a category that always causes difficulty to non-native speakers of a language, and one of the first elements of vocabulary one avoids when there are communication difficulties. Such verbs are of course, almost exclusively non-latinate, and cause difficulties of comprehension due to their similarities, due to the large number of phrasal and prepositional verbs with more than one meaning, and due to the fact that it is often not possible to calculate the meaning of a phrasal verb by adding the meanings of its component parts. In fact, knowing some of the senses of the component words can be a brake on understanding. People who understand the word "crop" are perhaps less likely to be able to handle "to crop up" than those who do not! Similarly with "to tuck in" (in the sense of to begin eating).

\section{Table 5. Phrasal verbs}

\begin{tabular}{|c|c|}
\hline to breeze into subjects (D5) & 1 \\
\hline to peel off ( from allies) (D17) & 4 \\
\hline to gulp down (D5) & 12 \\
\hline to dart about (D14) & 10 \\
\hline the wooziness of barely diluted power is getting to him. (D13) & 16 \\
\hline to rein back (US capitalism)(D12) & 20 \\
\hline to ride out (a crisis) (D13) & 34 \\
\hline to snap at (someone) (D5) & 37 \\
\hline to snip away at (the deficit) (D5) & 42 \\
\hline to chip away at (our institutions) (D9) & 47 \\
\hline to clamp down (D1) & 69 \\
\hline to tuck into (D11) & 82 \\
\hline to fall out with (someone) (D10) & 87 \\
\hline to fork out (D4) & 122 \\
\hline to fend off (D13) & 140 \\
\hline to bail someone out (D18) & 129 \\
\hline
\end{tabular}




\begin{tabular}{|l|c|}
\hline to back this up (D10) & 171 \\
\hline to write off (a debt) (D18) & 272 \\
\hline to crop up (D16) & 302 \\
\hline to stand up to (SE Asia's elder statesman) (D18) & 367 \\
\hline
\end{tabular}

There were a number of proverbs and idioms in the documents.

Table 6. Proverbs and idioms

\begin{tabular}{|l|l|}
\hline to go nuclear (D17) & 2 \\
\hline men with beetle brows (D13) & 2 \\
\hline collateral damage (D17) & 4 \\
\hline Dyed-in-the-wool monarchists (D9) & 4 \\
\hline to cut and run (D11) & 12 \\
\hline to line one's pockets (D4) & 18 \\
\hline a bushel of carrots and one very big stick (D7) & 33 \\
\hline to call the shots (D13) & 39 \\
\hline a moot point (D12) & 53 \\
\hline a tall order (D14) & 59 \\
\hline He will cut no ice with the students (D18) & 20 \\
\hline to walk tall (D17) & 21 \\
\hline to come a cropper (D16) & 34 \\
\hline to loom large (D19) & 76 \\
\hline to turn a blind eye (D10) & 183 \\
\hline hold no balm (D19) & 31 \\
\hline
\end{tabular}

Naturally the most difficult among these are the ones where the original expression or proverb is twisted for ironic effect (as in "a bushel of carrots and a very big stick".)

34 Apart from the above categories of vocabulary, we identified a series of culturally based expressions difficult to categorise -forms of intertextuality which depend heavily on a knowledge of British culture. 
Table 7. Culturally-based expressions

\begin{tabular}{|l|l|}
\hline Parts that money cannot reach (D1) & 8 \\
\hline (various references to original quotation “the parts other beers cannot reach") & 15 \\
\hline A billion Chinese won't be wrong (D8) & 0 \\
\hline (in its original form: “a million housewives can't be wrong") & 3 \\
\hline An idea whose time has passed (D9) & 0 \\
\hline (as the original quotation "an idea whose time has come") & 8 \\
\hline There's no such thing as social product (D10) & 0 \\
\hline (as its original quotation from Margaret Thatcher "There's no such thing as society") & 8 \\
\hline deadbeat dads (D7) & 5 \\
\hline $\begin{array}{l}\text { That view would be harmless if it were limited to Troubled of Tunbridge Wells or Bothered } \\
\text { of Baltimore. (D8) }\end{array}$ & 0 \\
\hline checks and balances (D9) & 58 \\
\hline goodbye to all that (D15) & 3 \\
\hline
\end{tabular}

Some of these examples of intertextuality involved texts which are almost never available to foreign speakers of a language. "A billion Chinese won't be wrong" is a reference to an advertising slogan from the 1960s for Heinz "A million housewives can't be wrong." "The parts that money can't reach" refers to an advertisement for Heineken -the beer which "refreshes the parts other beers cannot reach".

"Troubled of Tunbridge Wells or Bothered of Baltimore" (D8) is a reference to stereotypical eccentric habitual writers of letters to the Editor.

Some of the references to US or British politics ("checks and balances" in D9) might be considered to be readily available to those with a passing knowledge of US civilisation. Nevertheless, some reference required a close knowledge of domestic politics in Britain or the US -thus "deadbeat dads" (D7), a recently coined phrase used to refer to fathers especially divorced or separated ones- who do not fulfil their parental responsibilities. Along the same lines, the documents contained a small number of non-English expressions, which gave the following results (see Table 8).

Table 8. Non-English expressions

\begin{tabular}{|l|l|}
\hline vaterland/Vater(D1) & 1 \\
\hline pour mieux sauter (D16) & 3 \\
\hline
\end{tabular}




\begin{tabular}{|l|l|}
\hline pro bono work & 4 \\
\hline folies de grandeur (D9) & 5 \\
\hline complaisant (D3) & 13 \\
\hline largesse (D3) & 81 \\
\hline coteries (D13) & 84 \\
\hline frissons(D1) & 106 \\
\hline
\end{tabular}

Examining the vocabulary of our sample of editorials and its frequency within the British National Corpus allowed us to draw some conclusions about lexical choice of the journalists concerned. It is clear that the journalists, while considering that they are "committed to plain English" are quite ready to employ words and expressions, which are extremely rare in real modern English.

Just how rare are these words? Obviously a precise measure of what is a rare word is impossible, but to give an idea, there are 6,318 words in the BNC which occur more than 800 times. In our list, it is very rare for one of the words to occur more than 300 times, and a large number occur only a handful of times in this hundred million word corpus.

41 We have already mentioned that our contact group who identified problematic vocabulary had a level of English much higher than that of the target audience of The Economist. For several other reasons, the account of vocabulary given above considerably underestimates the difficulty involved for the target audience.

Firstly, to measure the frequency of apparition of the lexemes within the British National Corpus is to measure their frequency in native English. However, everyday native English is not the English experienced by non-native managers in their work. They are much more likely to be involved in international meetings with other non-native speakers than with British people. We can imagine then, that vocabulary which is rare in the BNC is far more rare in the everyday non-native English that The Economist's readers hear every day. This must in particular be true for the complex adjectives and nouns, and the phrasal and prepositional verbs which are common in the sample of lexis we examined.

Secondly, our sample of The Economist writing takes only one page per issue, twenty pages in all. Each issue of The Economist contains 108 pages, including seven or eight editorials, and the magazine is published every week. Readers are therefore expected to be able to handle very large quantities of such text.

It seems that contrary to the claims of The Economist to be "committed to plain English", and in spite of frequently expressed fears among English Language professionals that "global English" will mean "simplified English", the lexis of these editorials contains a large number of words and expressions which are at best problematic and at worst incomprehensible for the type of people at which they are aiming.

What could be the reason for this? The first element to look at is the intrinsic complexity of the subject matter. The discussion of general global strategy for businessmen and state governments, and the attempt to persuade the reader of the appropriateness of particular measures obviously require a high level of complexity in the expression of opinion, and of 
interpretation. Nevertheless, it seems unlikely that the nature of the language used is in the main due to the functional necessities attached to discussing complex strategic issues. It would be perfectly possible to avoid slang and cultural references, phrasal verbs and complex adjectives.

It seems more likely that the reasons for the choice of vocabulary by the journalists of The Economist lie outside the domain of the practical needs of communication.

Firstly, we should look on The Economist's "commitment to Plain English" objectively. It is a statement that has to be taken as having an ideological content, rather than being simply a description of the language they use. "Plain English" can be taken as one of the weapons recommended by The Economist team against those elements of modern society ( bureaucracy and excessive rule making) which they consider to have caused so much damage. The free-market politics of the magazine have an indirect link with the type of English they believe is most important. Free-market politics has frequently -especially in the last twenty years - been linked in the Anglo-Saxon world with a demand for "pragmatism" or "common sense".

In this context, the frequently expressed rejection of "jargon" by the writers of The Economist is interesting. In reality, as any in-company trainer in English as a Foreign Language knows, "jargon" is by far the easiest vocabulary for non-native businessmen. "Re-engineering", "Brand enhancement", "Benchmarking" "Customer delight" are jargon terms which rapidly spread around the world of international business, much more easily than do the type of heavily culture-based expressions we have seen above. The rejection of jargon is the rejection of the discourse of "the expert" and the underlining of the assumed superiority of the ordinary, down-to-earth person-in-the-board room. This links up with the use of anonymous articles in the magazine.

The link between Thatcherist politics and "plain English" has been seen elsewhere. Margaret Thatcher herself, according to her biographer Hugo Young

was impatient with what she regarded as pretentious intellectual language. One reason she mistrusted the Foreign office was its habit of employing a 'frenchified' vocabulary. In her mind, English nationalism seemed to have a close link with plain English usage.

50 If our sample of editorials shows the very opposite of "plain English", and certainly the opposite of any form of simplified English, how can we view it. One might see in it a form of Babu English. Widdowson (1979: 202ff) defines Babu as a type of language which has diverged in the opposite direction from Pidgin English. Pidgin English he defines as a style of discourse in which the referential force -the need to refer to the outside worldis paramount. For example, traders or insurance salesmen neither of whom are native speakers of English may resort to Pidgin English as sufficient for their aims.

51 Babu is the opposite of Pidgin - when the poetic force of a discourse outweighs its referential force.

In babu, it is the expression which receives primary emphasis. Here how you say something is more important than what you say ... (Widdowson, 1979: 202)

Widdowson continues,

Just as we recognise that pidgin characteristics appear in 'normal' kinds of communication like telegrams and newspaper headlines... where the referential force is dominant, so we can recognise kinds of language use which have some of the characteristics of babu, where the poetic force is dominant. Examples abound in political speeches, sales patter, and the kind of prepared commentary given by guides showing people round places of historic interest. (203) 
It seems to us that The Economist editorials do have elements of babu English. Showing the (anonymous) writers as sophisticated men of the world wielding sharp edged irony and "straight no-nonsense speaking" is an important part of the role of an editorial.

Yet there is a concept from discourse analysis developed by Alan Bell (1991) which seems to us to be more useful still for analysing the reasons for the lexis chosen by The Economist . It is that of "referee design". In his book, Bell explains:

Referee design is a rhetorical strategy by which speakers use the resources available to them from their speech community... Referee strategies may be limited to creative use of the linguistic repertoire of styles or languages which a speaker herself [sic] normally employs. Or the strategies may draw on a wider speech community. (Bell 1991: 127)

Fundamentally, referee design amounts to treating the addressee as if they were someone else, for rhetorical purposes. In the simplest form of referee design

...speakers can persuade a stranger by shifting to the style normally reserved for intimates. (ibid.)

5 It may be that the editorialists of The Economist are following a form of referee design, bringing the reader into a "referee group" -an in-group to all intents and purposes. That is, that rather than addressing the international readers in a style chosen for ease of communication, they are addressing them in a way that suggests they the readers master the subtleties of the English language totally, and can easily take in complex cultural references and intertextuality in English.

To give just one example, the expression "geek-hero" as a description of Bill Gates at the beginning of his career could have been replaced by an expression such as "the hero of antisocial computer enthusiasts". It would certainly lose some literary colour (an "enthusiast" does not necessarily wear glasses and an anorak), but more importantly, it would subtly change the design of the referee group in the communication process.

Explanations for the presence of babu and for the design of such a referee group are necessarily speculative, since they are almost certainly unconscious. One possible explanation is that of legitimisation. The Economist represents its readers as "world leaders" -the people who take humanity forward. This image requires that the in-group also be presented as culturally worthy of being the leading group. Highly sophisticated styles of communication, and design of an in-group are part of this process of legitimisation. Other elements of this same legitimisation are to be found in the choice of contents of The Economist magazine, where Art, Science, and occasionally Rock music and cinema help to design the in-group in question -a sort of new Renaissance Businessman.

This study of the English of The Economist editorials confirms the close relationship between the communication task and the lexical characteristics of the English used in the business world (see Mullen 1998). It also tends to suggest that a "world business English", simplified for mass use, is not likely to occupy all the roles of English within business. Discussion of business, economic and political strategy, at least, seems to be well protected from any such trend. The language of international business magazines certainly offers much further scope for study, whether from the point of view of rhetoric or of discourse analysis. 


\section{BIBLIOGRAPHY}

Bell, Allan. 1991. The Language of News Media. Oxford: Blackwell.

Brouat, Thérèse. 1994. "L'intertextualité dans les accroches publicitaires". Cahiers de l'APLIUT 14/2, 73-96,

Calvet, L-J. 1993. La sociolinguistique. Coll. Que sais-je? Paris: Presses Universitaires de France.

Clijsters, W. 1990. Mille lettres d'affaires en chiffres. Paris \& Genève: Champion-Slatkine.

Crystal, David. 1995. The Cambridge Encyclopaedia of the English Language. Cambridge: Cambridge University Press.

Ferraro, M. 1990. The Cultural Dimension of International Business. New Jersey: Prentice Hall. Geis, Michael L. 1987. The Language of Politics. New York: Springer Verlag.

Heald I. \& R. Zajac. 1996. Syntactic and Semantic Problems in the Use of a Controlled Language, Proceedings of the First International Workshop on Controlled Language Applications - CLAW 96, Centre for Computational Linguistics, Katholieke Universiteit Leuven, Belgium, 205-215.

Hennot, Jacques. 1993. La Presse économique et financière, Paris: Presses Universitaires de France.

Hollqvist, Hakan. 1984. The Use of English in Three Large Swedish Companies. Uppsala: Studia anglistica upsaliensa.

Lerat, P. 1996. Les langues spécialisées. Paris: Presses Universitaires de France.

Lerat, P. 1997. “Approches linguistiques des langues spécialisées”. ASp 15-18, 1-10.

McCrum, Robert, Cran, William \& Robert MacNeil. 1986. The Story of English. London: Faber \& Faber,

Molinié, G. 1991. La stylistique. Coll. Que sais-je? Paris: Presses Universitaires de France.

Mullen, John. , 1998. “Anglais de métier: la simulation des tâches professionnelles en cours d'anglais". ASp 19-22, 425-431.

Sturge Moore, Olivier. 1997. "La mondialisation de l'économie: de nouveaux enjeux, de nouveaux contextes culturels”. ASp 15-18, 325-338.

Swales, J.M. 1990. Genre Analysis, English in Academic and Research Settings. Cambridge: Cambridge University Press.

Truchot, Claude. 1994. “The spread of English in Europe”. Journal of European Studies 24, 141 - 151. Watbled, Jean-Philippe. 1998. Les mots de l'anglais. Paris: Nathan.

Widdowson, H.G. 1979. Explorations in Applied Linguistics. Oxford: Oxford

Young, Hugo. 1989.One of Us. Basingstoke: Macmillan.

\section{Electronic sources}

The British National Corpus can be consulted on-line at http://www.natcorp.ox.ac.uk/. This site allows a simple search query. More sophisticated searches can be carried out with software purchased at this site. 
The Plain English campaign has its website at http://www.plainenglish.co.uk, which was a useful source for examining the ideology and significance of "plain English".

\section{NOTES}

1. E-mail communication from Anthony Green on TESL-L, an electronic discussion list for EFL teachers.

\section{ABSTRACTS}

It has often been suggested that international business English is simplified English, and/or that international business English is bound to lose its cultural roots altogether. Yet in the strategy discussions of The Economist, a high level of lexical complexity is found. This paper examines the choice of vocabulary in the Economist editorial and proposes explanations for their choices in terms of the need to legitimise their position and discourse.

On a souvent suggéré que l'anglais international des affaires est d'une nature simplifiée et s'est séparé de ses racines culturelles. Pourtant, dans la rubrique "stratégies en affaires" de The Economist, nous avons remarqué une complexité lexicale très marquée. Le présent article examine les choix lexicaux dans les éditoriaux de cette revue et en propose une analyse explicative.

\section{INDEX}

Mots-clés: analyse du discours, anglais des affaires, anglais international, babu, conception d'arbitre, élite, journalisme, lexique, style

Keywords: discourse analysis, in-group, journalism, lexis, referee design, business English

\section{AUTHOR}

\section{JOHN MULLEN}

Après son doctorat en civilisation britannique, John Mullen a travaillé longtemps dans la formation en entreprise en tant qu'enseignant et responsable de la conception des programmes. Il est actuellement maître de langues, responsable de l'enseignement de l'anglais dans l'UFR de Biochimie de l'Université Descartes Paris 5. john.mullen@wanadoo.fr 